\title{
Constructing Science Knowledge in Linguistically Diverse South African Classrooms: Opportunities and Challenges for Learning
}

\author{
Margaret Probyn, University of Western Cape
}

\begin{abstract}
Introduction
South Africa is by definition a diverse country, reflecting its colonial past and history of migrations. However, under apartheid that diversity was the foundation of political domination based on the strict enforcement of social, economic, linguistic and spatial separation according to race. Accordingly, there are tensions between the celebration of diversity and the goals of national unity, equality and social justice in post-apartheid South Africa. This is reflected in the motto on the new national coat of arms:!ke e: /xarre //ke, which literally means 'Diverse people unite' in /Xam, a minority Khoisan language. These tensions also play out in linguistically diverse classrooms and in part shape the challenges and opportunities for teaching and learning. These issues are
\end{abstract}

How to cite this book chapter:

Probyn, M. 2019. Constructing Science Knowledge in Linguistically Diverse South African Classrooms: Opportunities and Challenges for Learning. In: Wright, C., Harvey, L. and Simpson, J. (eds.) Voices and Practices in Applied Linguistics: Diversifying a Discipline, pp. 211-232. York: White Rose University Press. DOI: https://doi.org/10.22599/ BAAL1.m. Licence: CC BY-NC 4.0 
explored in this chapter, in line with the theme of diversity and applied linguistics in this volume.

The first democratic elections in South Africa in 1994 marked the end of apartheid and the dawn of a new social, political and economic order. This included the constitutional recognition of nine African languages as official languages (isiZulu, isiXhosa, Sepedi, Setswana, Sesotho, Xitsonga, Siswati, Tshivenda, isiNdebele) in addition to the former colonial languages of English and Afrikaans (Republic of South Africa 1996). In addition, significant policy initiatives were introduced to transform the education system, based on the principles of access, equity and redress. However, 24 years on, inequalities in the education system have proved hard to shift and the South African education system remains fractured along lines of class, poverty and language, producing a 'bimodal' distribution of academic achievement (Fleisch 2008): a minority of middle-class learners at well-resourced schools that were formerly reserved for 'white' and Indian children perform at levels comparable to their peers internationally, while the majority of working-class and poor learners in under-resourced township ${ }^{1}$ and rural schools mostly perform at levels equivalent to several grades lower.

The disadvantages of poor socio-economic background and for learners in township and rural schools are compounded by the fact that from the fourth grade on they switch from learning through the medium of their home language to learning through the medium English, irrespective of their English language proficiency. While the language medium has been identified as a contributing factor to the poor performance of South African learners in international assessments of science such as TIMMS (Reddy et al 2015), in such large-scale quantitative studies it is difficult to disentangle language from other co-occurring factors that constrain learners' opportunity to learn. The research described in this chapter therefore set out to closely examine closely the languaging practice of teachers and learners in a small-scale multiple case study of eight township and rural schools where the home language of the teachers and learners was an African language, isiXhosa, and the official language of teaching, learning and assessment was English.

The research questions that guided the research were what opportunities to learn science are the learners in a sample of South African rural and township schools afforded and what is the role of classroom language in constructing or constraining such opportunities to learn?

\section{Linguistic ecologies of classrooms}

Classroom language practices in multilingual settings are nested within and shaped by particular language ecologies (Creese \& Martin 2008) including language policies, perceptions and practices, which in turn have their roots in history, political contestation, social practices and economic realities. South Africa is no different in this respect. 
The geographic distribution of languages in the country reflects the apartheid past when race and language were criteria for social, economic, politi$\mathrm{cal}$ and spatial segregation. Although there is significant linguistic diversity in urban centres, rural and township communities are often relatively homogenous linguistically, and children may grow up hearing only a local African language, with little exposure to English outside the classroom (Heugh 2002). The recognition of African languages as official languages in the new constitution was intended to enhance their status and expand their domains of use in public life. However, the force of coloniality (Christie \& McKinney 2017) and the global hegemony of English have meant that English has continued to dominate the political economy, despite being the home language of less than $10 \%$ of the population. In the context of widespread poverty and unemployment ${ }^{2}$ the perception is that 'English puts bread on the table' (Probyn et al. 2002) and so English remains the language of aspiration for upward mobility and escape from the poverty trap.

In line with the Constitution, the Language-in-Education Policy (LiEP) (Department of Education RSA 1997) aimed to develop societal and individual multilingualism in order to further the goals of building of a non-racial nation and achieving redress for previously marginalised African languages. In terms of the LiEP, learners are required to study two official languages, one of which should be the medium of instruction or language of learning and teaching (LoLT). In addition, the choice of LoLT should follow the principle of 'additive bilingualism' by maintaining the learners' home language/s, while 'providing access to and the effective acquisition of additional language/s' (Department of Education RSA 1997: 2). However, the state has abdicated decision-making on school language policies to school governing bodies made up of parents and teachers (and, in secondary schools, learners), reflecting a lack of political will on the part of government to give practical effect to policy intentions. In addition, the arguments and research evidence in support of home language LoLT (UNESCO 1953; Bambgose 1991; Thomas \& Collier 2002) have not been widely disseminated, so the instrumental need to acquire English, plus the widespread common-sense perception that English proficiency is best achieved through time on task, has led to school governing bodies deciding in favour of an early switch to English LoLT (Plüddemann 2015). The result is that, by Grade 4, the official language of learning and teaching is English for the majority of learners.

National demographics mean that learners in historically disadvantaged township and rural schools have little interaction with English speakers, and research has shown that there are few written resources in these communities and homes to support literacy or English learning outside the classroom (Howie et al. 2017). Consequently the majority of learners do not achieve the necessary levels of English proficiency to access the curriculum, making learning akin to 'swimming up a waterfall' (Macdonald 1990). This results in the apparent paradox that the language so desired for upward mobility in fact poses a devastating barrier to learning and educational achievement. 
In classrooms teachers are faced with the challenges of teaching through the medium of a language that learners do not fully comprehend, a challenge for which they are not prepared in teacher training (Probyn 2001). As a result there is frequently a gap between language policy and classroom practices, with many teachers resorting to alternating between English and the learners' home language/s for a range of cognitive, classroom management and affective purposes (Ferguson 2003). Although such strategies are advocated in the research literature (Ferguson 2003), there are mixed and shifting messages on the matter from South African education authorities and this creates uncertainly and tension for teachers (Setati et al. 2002; Probyn 2009). The result is that, contrary to the educational goals of equity and access, language in education policies and practices have resulted in differentiated access to the curriculum, entrenching historic patterns of disadvantage.

This is the context for the study reported here. The debates and research on the language/s of learning and teaching in South Africa have tended to overshadow studies of the nature of the classroom discourse and how teachers and learners engage in constructing knowledge though classroom talk - an aspect that has received considerable attention in contexts that are generally more linguistically homogenous. In order to examine the role of language in constructing or constraining opportunities to learn, it seems necessary to go beyond a consideration of the language/s of learning and teaching and to consider too the nature of the classroom discourse and the interplay of both aspects of classroom language. This study therefore draws together these two different perspectives from the literature on language and learning: classroom discourse and of multilingual classroom practices in relation to the teaching and learning of science.

\section{Theoretical framework}

The framing concept for this study was that of 'opportunity to learn' (OTL), which holds that 'students can only be accountable for their academic performance to the extent that the community, broadly defined, has offered them the tools to master the content expected of them' (McDonnell 1995: 312).

For the purpose of this study, opportunity to learn science was conceptualised in terms of the science content of lessons (the what) and the language used to construct that science knowledge (the how). According to Donovan and Bransford (2005), a key aspect of learning science content with understanding is that of conceptual coherence: facts should be linked to generalised conceptual frameworks; and conceptual frameworks themselves should be supported by rich factual detail.

In line with this, Wellington and Osborne (2001: 83) have emphasised the importance of discussion in science lessons, in order to '[link] evidence and empirical data to ideas and theories'; Scott, Mortimer and Ametler (2011) have 
pointed to the importance of learning how 'scientific concepts themselves fit together in an interlinking system' as an aspect of 'pedagogical link-making' (p. 8). It is through the classroom discourse that such pedagogical link-making must needs happen, and so the literature on classroom discourse was an important frame for the research.

The analysis of classroom discourse drew on Barnes's $(1976,1992)$ distinction between 'exploratory talk' by learners where the focus is on sorting out their own ideas and 'presentational talk' when they offer a 'final draft' for display and evaluation. In addition the analysis identified discourse interaction patterns, drawing on Gibbons's 2006 study, in particular the notion of 'dialogic talk': whole-class talk that extends the pervasive Initiation-ResponseEvaluation (IRE) patterns of interaction to build on learners' responses in what Wells (1999) has described as 'contingent responsiveness' on the part of the teacher. In this way the teacher guides learners in linking ideas into coherent lines of thinking (Alexander 2000) and the co-construction of knowledge (Mercer 1995).

Mortimer and Scott (2003) have pointed out that, in science lessons, practical work does not speak for itself, but it is in the interactive talk during and following practical activities that the learning of the science concepts takes place (p. 1 ), and that, while it is important for learners to have the opportunity to discuss their own ideas, they 'will not stumble upon, or discover, the key concepts ... of science for themselves' - they need an 'authoritative introduction to the scientific point of view' (p. 106). So 'there will always be a tension between dialogic and authoritative discourse and a key part of the teacher's role is to strike an effective balance between [the two]' (pp. 106-107). Thus classroom discourse is the means though which the vertical knowledge structure of science may be constructed by teachers and learners.

Classroom discourse may also serve to bridge the gap between the learners' home language and school language in general and the language of school science in particular. Research by Gibbons (2006) has shown how good teachers may orchestrate a 'bridging discourse' during teacher-guided reporting back by students in order to support learners as they move across the oral to written mode continuum: shifting from face-to-face, context-embedded talk around practical activities that utilises everyday knowledge and language - what Bernstein (1999) has referred to as horizontal discourse - to using more abstract, context-reduced, generalised, scientific knowledge and language - Bernstein's vertical discourse.

In linguistically diverse contexts such as South Africa, there is frequently an additional layer of bridging discourse as many teachers utilise the learners' home language as a bridge to understanding the lesson content in English (Setati et al. 2002; Probyn 2009). Cummins (2008) has long proposed the interdependence of languages and the transfer of literacy and cognitive proficiency across languages through explicitly 'teaching for transfer.' In line with this has been an acknowledgement of 'the fluid ways in which languages are used' in 
multilingual contexts, including 'translanguaging' (Garcia 2009). This reflects a heteroglossic orientation to language in the classroom and a flexible, systematic use of classroom language resources to mediate learning. The research study reported in this chapter is a further contribution to the understanding of the 'emergent educational concept' of translanguaging (Lewis, Jones \& Baker 2012: $667)$ and what it might mean in classroom practice in postcolonial contexts such as such South Africa.

Thus this study draws on research and theories relating to science education, classroom discourse and pedagogical translanguaging in order to analyse the data and arrive at conclusions as to what classrooms languaging practices construct or constrain the opportunity to learn science in typically poor township and rural classrooms in South Africa.

\section{Research design}

In order to investigate language and the opportunity to learn science, a multiple case study was undertaken in Grade 8 science classes in eight township and rural schools in the Eastern Cape Province of South Africa. The Eastern Cape is one of the most under-developed and poorest of the nine provinces, with only $26 \%$ of the population employed according to the 2011 census (Statistics South Africa 2014). isiXhosa is the home language of $78 \%$ of the population and, in the two rural districts in the study, isiXhosa was the home language of $92 \%$ and $87 \%$ of the population; in the urban district where the township schools were located, isiXhosa was the home language of $77 \%$ of the population.

\section{School contexts}

The eight schools in the study exemplified the contexts that have given rise to the 'bimodal' patterns of academic achievement in South African schools generally and in science in particular.

Five of the schools were located in rural villages, consisting of scattered mud and thatched huts and occasional cement-block houses. Most residents subsisted on small herds of cattle or goats and vegetable gardens, and the main sources of income were fairly meagre social grants. According to the teachers, many children lived with grandparents as their parents were working in the cities, and there were an increasing number of child-headed households. Three of the schools were located in a sprawling peri-urban township, with a mix of small, closely packed formal housing and informal shacks. More learners lived with their parents but here too there was widespread unemployment and poverty.

The rural school buildings were old and dilapidated, with pit latrines, and two schools had only mud and dung floors. Two of the five rural schools had 
no water supplies and so the teachers had to bring water to school in bottles to conduct science experiments. Only one of the rural schools had electricity, and the supply was unreliable. The three peri-urban township schools had bigger and more substantial school buildings, with electricity, reliable municipal water supplies and flush toilets.

Textbook supplies varied: one rural school had enough textbooks for each learner but in the other schools learners had to share textbooks or only old textbooks pre-dating the new curriculum were available. None of the schools had any science laboratories or equipment for practical work, beyond what teachers could improvise themselves.

Thus the opportunity to learn science in these schools was constrained by socio-economic and domestic factors and historic disadvantage in the material conditions in the schools - factors that combined to restrict learners' opportunities to learn science.

In addition, the common home language of learners and teachers was isiXhosa, with learners receiving very little exposure to English outside the classroom. Teachers considered that learners' proficiency in English was generally poor and that English constituted an obstacle to learning.

\section{Data collection and analysis}

Data were collected from five consecutive Grade 8 science lessons that were observed and video-taped for each of the eight classes. The lesson transcripts were analysed using sociocultural discourse analysis (Mercer 2004) to trace the development of science knowledge within and across lessons, and the language that was used to construct that knowledge. The analysis took into account the classroom discourse patterns as well as the languaging practices of teachers and learners.

The unit of analysis for mapping the development of science content through language was the series of five lessons per teacher. The public talk in the lesson transcripts was coded and analysed for 'opportunity to learn' science as outlined below. 'Public talk' was defined as talk by teachers or learners where the intended audience was the whole class or during group work where the teacher's talk to a group could be heard by the whole class.

In order to map the lesson structure and to provide a framework for the analysis of the development of content through language, each lesson was divided into lesson 'episodes.' These are defined by Gibbons (2006: 95, following Lemke 1990: 50) as 'a unit of discourse with a unifying topic and purpose' - roughly equating to a teaching activity. The lesson episodes provided the structural framework for the process of data analysis. The facts presented per episode were identified and provided the basis for analysis of the lesson content. The classroom discourse was analysed in terms of the balance of teacher-learners talk per episode; the discourse interaction patterns for each episode; evidence 
of bridging discourses (i.e., instances of teachers providing support to learners in bridging the gap between everyday knowledge and science knowledge); everyday language and science language; practical and theoretical knowledge and spoken and written language.

The bilingual languaging practices of teachers and learners were coded for the use of English and isiXhosa in terms of word counts for each language; the functions of the teachers' and learners' use of isiXhosa (following Ferguson 2003): for constructing and transmitting science knowledge; for classroom management; and for sustaining interpersonal relations.

The bilingual languaging practices of teachers and learners, along with the classroom discourse patterns, were mapped onto the lesson episodes and science content of lessons.

\section{Findings}

The research study set out to investigate the role of language in constructing or constraining the opportunity to learn science in linguistically diverse classrooms in a sample of township and rural schools. In the reporting of the data, teachers have been assigned the pseudonyms A-H.

It appeared from the analysis of the data that the opportunity to learn science was markedly greater in the practice of one teacher (Teacher B). What distinguished his practice from that of the other seven teachers were the greater levels of coherence of the science content in his lessons and therefore greater opportunities to learn science with understanding; the evidence in his lessons of dialogic learning discourse to achieve the coherence of science content; and his greater use of the learners' home language in a systematic bridging discourse that could be described as pedagogical translanguaging.

\section{Pedagogical translanguaging for learning}

The analysis of the teachers' and learners' languaging practices took account of the relative frequency of use of their common home language, isiXhosa, and the official language of learning and teaching, English. The broad functions of teachers' use of the learners' home language, where this occurred, were categorised. This analysis provided the basis for a consideration of the pedagogical value of such practices and whether or not they constructed or constrained the opportunity to learn science in the observed lessons.

The results are shown in Figures 11 and 12 below. Teachers' and learners' language use have been separated to make the patterns of learner talk clearer, as the levels of learners' language use was so much less than that of the teachers note that the values along the y-axis for the teachers in Figure 11 are about 10 times those for the learners in Figure 12. 


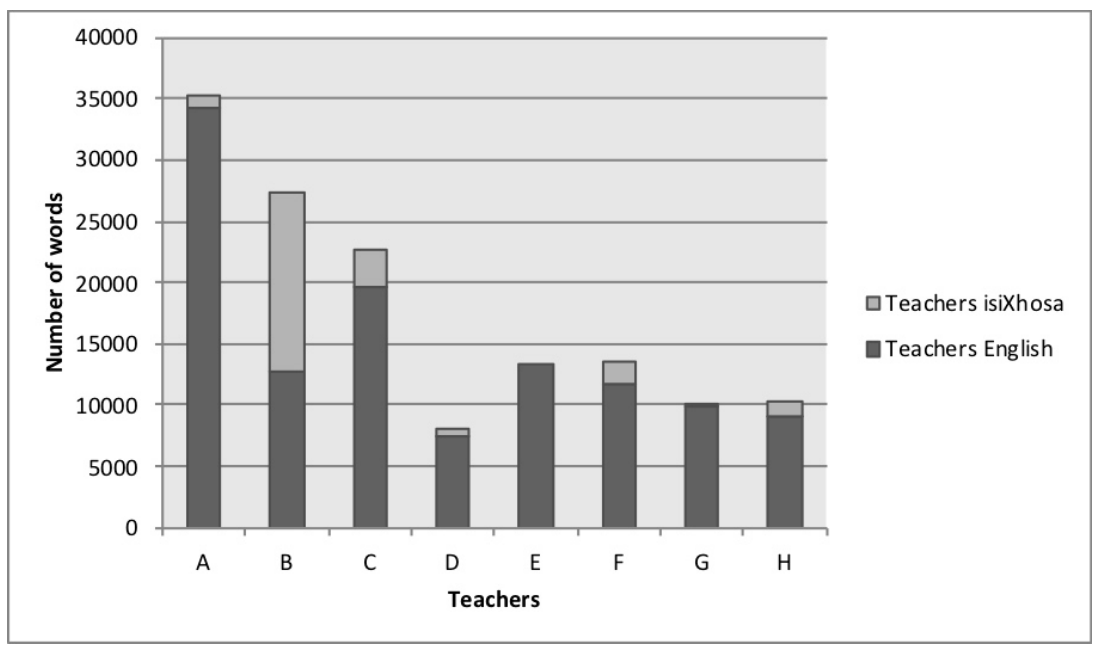

Figure 11: Teachers' use of isiXhosa and English by word count (Copyright Margaret Probyn, CC BY-NC 4.0).

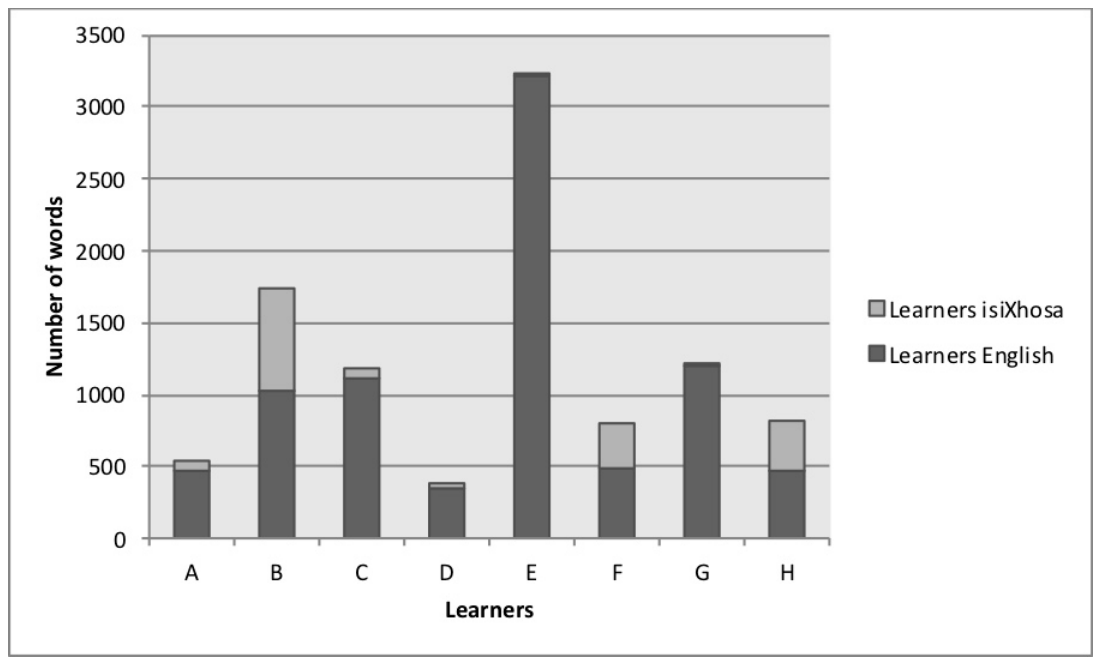

Figure 12: Learners' use of isiXhosa and English by word count (Copyright Margaret Probyn, CC BY-NC 4.0).

As the chart in Figure 11 shows, there was a wide range in terms of the teachers' use of English and isiXhosa: Teacher B used more isiXhosa than English (53\% isiXhosa and 47\% English), whereas the other teachers used far more English than isiXhosa, ranging from $87 \%$ English (Teachers C and F) to $100 \%$ English (Teachers E and G). 
Similarly there was a wide range of learners' language use (see Figure 12): learners in Classes B, F and $\mathrm{H}$ used almost the same balance of languages: 42\%, $39 \%$ and $43 \%$ isiXhosa, respectively, while learners in Classes A used 13\% isiXhosa, learners in Class D 11\% and learners in Class C 6\%; learners in Classes E and $\mathrm{G}$ used no isiXhosa.

Word counts alone do not indicate what effect the bilingual languaging practices of teachers might have on the learners' opportunities to learn science and so one needs to have a closer look at the ways in which different teachers and learners utilised the linguistic resources available to them. What follows therefore is an analysis of the functions of the teachers' and learners' use of isiXhosa, following the categories below, as suggested by Ferguson (2003), and a consideration of whether these languaging practices appeared to support learners' opportunities to learn science.

- Constructing and transmitting knowledge: this would include science content knowledge as well as reference to learners' own experiences in support of understanding the science content.

- Classroom management: this would include regulative discourse - instructions intended to organise learning, and discipline in the form of rebukes.

- Interpersonal relations: 'to humanise the affective climate of the classroom' (Ferguson 2003: 39). This would include banter not related to the lesson content and encouragement such as Heke! ('Good!').

What is clear from the chart in Figure 13 is that Teacher B made far more use of isiXhosa to communicate the science content of lessons (32\% of classroom talk) than did the other seven teachers (between $0 \%$ and $10 \%$ ).

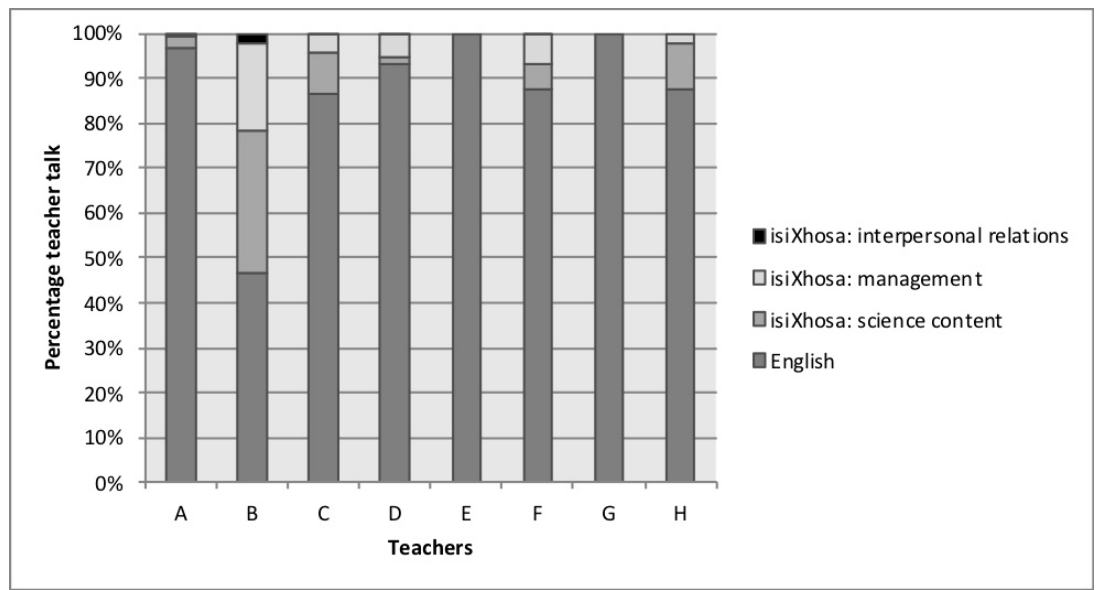

Figure 13: Functions of teachers' isiXhosa talk in relation to total classroom talk (Copyright Margaret Probyn, CC BY-NC 4.0). 
So, despite the fact that all the teachers had said in the interviews that they would use isiXhosa to explain science content if necessary, there was relatively little evidence of this overall in the observed lessons of seven out of the eight teachers. Reactivity might well have contributed to the relatively low levels of isiXhosa use by these teachers, but this also indicates that seven of the eight teachers did not consider the learners' home language a legitimate resource to improve learners' opportunity to learn science.

\section{Pedagogical value of classroom language alternations}

Literature on classroom code-switching is based mainly in postcolonial settings, where the medium of instruction is a former colonial language, which is not the home language of the learners. It appears such strategies are largely unplanned and very often unconscious and are mostly reactive - in response to the teacher's perception that learners had not understood part of the lesson content being delivered in English.

Constructivist ideas on language and learning in general suggest that faceto-face exploratory talk (Barnes 1976, 1992) in groups would usually precede more context-reduced 'presentational talk.' Gibbons (2006) has described the teacher's role in mediating and scaffolding this process of moving from exploratory to presentational talk in whole-class discussion, which is then a preparation for writing and thus scaffolding a move across the mode continuum.

Science lessons are typically structured in terms of a review of existing knowledge on a topic, introduction of new ideas - often though practical activities - discussion and making sense of the practical work in terms of linking it to science theory and then writing and consolidation of the new ideas in some form, and so in science lessons the teacher's scaffolding of this process of moving from exploratory to presentational talk would occur in the whole-class discussion following practical work in groups (Gibbons 2006).

In a multilingual context, it would seem logical to develop learners' knowledge in their home language and then transfer this understanding to the second/ additional language (L2) - what Cummins (2008) has described as 'teaching for transfer.' Setati et al. (2002) referred to teachers and learners moving from 'informal, exploratory talk in the learners' main language(s) to discourse-specific talk and writing in English' (p. 72) and proposed that teachers might take various routes to complete this 'journey'.

This would suggest using the learners' home language for exploratory talk both in group discussions by learners or teacher-led exploratory talk when making sense of practical work and developing new understandings and then transferring this understanding to the additional language, first orally (see Clegg \& Afitska 2011) and later in writing.

This would amount to a strategic and systematic use of two languages - what could be described as translanguaging - rather than a more reactive codeswitching from the LoLT in response to signs of incomprehension on the part 
of learners - by which time critical gaps and misconceptions about the science content might well have developed.

What the research data indicated is that only one teacher (B) appeared to use isiXhosa to 'work on understanding' (Barnes 1976, 1992) in a systematic way. The other teachers who made use of isiXhosa to communicate science content for between $3 \%$ and $10 \%$ of classroom talk generally did so in the form of fairly brief code-switching from the LoLT. These teachers also said that they would switch to isiXhosa in response to cues from the learners that they had not understood:

Teacher C: When I look at them I can see that some of them don't understand. ... I can see if they are uncomfortable, from their faces and I can see ... mmm ... they don't understand so I must repeat this in their mother tongue.

It seems likely that these forms of language alternation would have helped learners to understand more of the lesson content than if the teachers had not codeswitched or translated at all. But the fact that these teachers appeared to wait for a cue from learners that they did not understand before switching to isiXhosa meant that learners might well have been left with misconceptions and gaps in their understanding of the science content that the relatively brief and unsystematic code-switching would be unlikely to fully resolve.

Teacher B, on the other hand, used far more isiXhosa for communicating science content (32\% of words spoken) than the other teachers, and he seemed to work with both languages in a more balanced and structured way - more in line with the notion of 'translanguaging' and the productive use of languages as suggested by Garcia (2009), Blackledge and Creese (2010), Canagarajah (2011) and Lewis, Jones and Baker (2012). When interviewed, Teacher B said that if he were teaching a new concept he would first do so in isiXhosa and then in English. A closer examination of the shifts in language use over the course of one lesson supported this.

In the lesson the teacher was establishing the principle that in a mixture, the properties of the component substances do not change. The lesson followed the following 12 stages:

1. Review: the teacher led a whole-class question and answer to review the key ideas from the previous lesson.

2. Group practical activity 1: setting up practical activity. Groups were given two teaspoons each of sulphur and iron filings and had to fill in a table identifying the colour and magnetism of each substance, then fill in the results in a table.

3. Group practical activity 1: conducting activity.

4. Reporting back findings from practical activity 1 .

5. Group practical activity 2: setting up practical activity. Groups had to mix the sulphur and iron filings and observe the colour and magnetism of the mixture, then fill in the results in a table. 
6. Reporting back findings from practical activity 2 .

7. Group discussion: setting up: learners to discuss a definition for mixtures.

8. Groups discuss a definition for mixtures.

9. Report back on discussion.

10. Lesson conclusion.

11. Whole-class discussion on why a magnet should be wrapped in paper (so that iron filings could be easily removed).

12. Conclusion.

As Figure 14 shows, the exploratory talk during the three group activities, with the teacher mediating (group practical 1 mediating; group practical 2 mediating; group discussion mediating) was mainly in isiXhosa: 73\%, 64\% and 95\% isiXhosa, respectively, by Teacher B; and 59\%, 92\% and 80\% isiXhosa respectively by the learners. However, during the review and reporting back activities presentational talk - both teacher and learners used more English than isiXhosa: 66\% English by the teacher and 100\% English by the learners during the review and, during the reporting back activities, 66\%, 60\% and 61\% English by the teacher, and $67 \%, 81 \%$ and $100 \%$ English by the learners. So Teacher B

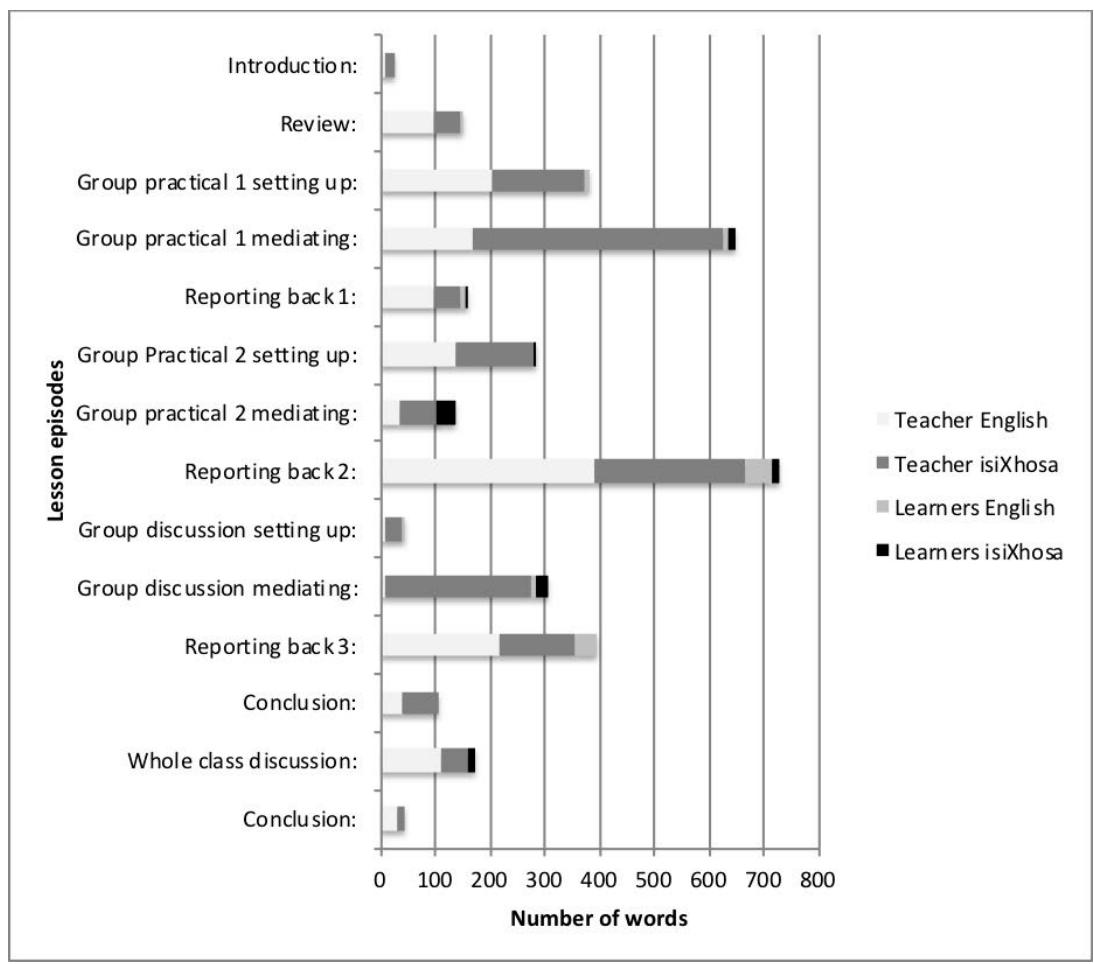

Figure 14: Translanguaging across a lesson (Copyright Margaret Probyn, CC BY-NC 4.0). 
tended to use more isiXhosa than English when working on meaning and then supported learners in transferring that understanding to English - what Cummins (2008) would describe as 'teaching for transfer.'

The following excerpts from the lesson transcript illustrate Teacher B's translanguaging across exploratory and presentational talk. The first excerpt was taken from the group discussion activity on defining a mixture and the next excerpt was taken from the reporting back that followed the group discussion. These illustrate the shift from exploratory talk in isiXhosa (100\% isiXhosa for both teacher and learners) to presentational talk mainly in English (78\% English for the teacher and 100\% English for the learners).

(Note that the isiXhosa is shown in italics and the English translation in square brackets immediately after.)

\section{Excerpt 1 - Exploratory talk}

\begin{tabular}{|c|c|c|}
\hline & Teacher B & Learner/s \\
\hline 1. & $\begin{array}{l}\text { Imixture yintoni kanti? [Then what is a } \\
\text { mixture?] }\end{array}$ & \\
\hline 2. & & $\begin{array}{l}\text { Learner: } u M x u b e \\
\text { [mixture] }\end{array}$ \\
\hline 3. & $\begin{array}{l}\text { Nina into eniyenzileyo ngoku nitshintshe } \\
\text { eligama eli nalisa esiXhoseni. Anichzi } \\
\text { ukuba yintoni kanye kanye le.Yabo? Yintoni } \\
\text { umxube? [what you have done is to change } \\
\text { the word into isiXhosa, you do not explain } \\
\text { what this really, really is. You see? What } \\
\text { is a mixture?] Njengalapha, yabona [just } \\
\text { like here, you see]? (pointing to mixture) } \\
\text { Yabona ukuba kuyacaca ukuba kwenzeka } \\
\text { ntoni [can you see it is clear what is } \\
\text { happening here]? (Indistinct) kwenzeke } \\
\text { ntoni [what happened]? }\end{array}$ & \\
\hline 4. & & $\begin{array}{l}\text { Learner: Kudibene into } \\
\text { ezmbini [two things have } \\
\text { mixed] }\end{array}$ \\
\hline 5. & $\begin{array}{l}\text { Kudibene into ezimbini [two things have } \\
\text { mixed]. Kwenzeka ntoni kwiproperties } \\
\text { zezozinto [what happened to their } \\
\text { respective properties]? }\end{array}$ & \\
\hline 6. & & $\begin{array}{l}\text { Learners: Azatshintsha// } \\
\text { Zatshintsha [Changed// } \\
\text { No change) }\end{array}$ \\
\hline
\end{tabular}




\begin{tabular}{|l|l|l|}
\hline & Teacher B & Learner/s \\
\hline 7. & $\begin{array}{l}\text { Zathini? Lungisani ke lonto. [What } \\
\text { happened? Go ahead and fix that then] } \\
\text { (refers to answer) }\end{array}$ & \\
\hline
\end{tabular}

\section{Excerpt 2 - Presentational talk}

\begin{tabular}{|c|c|c|}
\hline & Teacher B & Learners \\
\hline 1. & $\begin{array}{l}\text { Mixture. You should look at i-properties zezazinto, } \\
\text { ne? [properties of those things, okay?] When you } \\
\text { have those two substances ... masimamele sonke. } \\
\text { [let's all listen] Xa si ne zazinto [when we have those } \\
\text { things]. When you have those two substances, } \\
\text { i-iron: iron filings nesulphur, ne [and sulphur, okay]? }\end{array}$ & \\
\hline 2. & & Yes \\
\hline 3. & $\begin{array}{l}\text { Then we put them together... what happens to } \\
\text { i-properties, mhmm? Do i-properties change or } \\
\text { remain the same? }\end{array}$ & \\
\hline 4. & & Remain the same \\
\hline 5. & They what? & \\
\hline 6. & & Remain the same \\
\hline 7. & Heke [Good]! They remain the same, heh? & \\
\hline 8. & & Yes \\
\hline 9. & $\begin{array}{l}\text { So, that's how we should ehh... define imixture } \\
\text { yethu [our mixture.] i-mixture is a substance } \\
\text { where you have mixed or you have combined two } \\
\text { substances, ne [okay]? }\end{array}$ & \\
\hline 10. & & Yes \\
\hline 11. & $\begin{array}{l}\text { And the properties of those two substances } \\
\text { remained what? }\end{array}$ & \\
\hline 12. & The same & //the same \\
\hline
\end{tabular}

\section{Excerpt 3 - Language practices that support the opportunity to learn science}

The factors that formed the basis for the analysis - science content and language - in practice interact and are intertwined in the process of teaching 
and learning; but they have been teased apart from one another for the purpose of the analysis.

The following excerpt from the data is included to illustrate how the different aspects of language work together in the practice of one teacher to support the opportunity to learn science with understanding. This excerpt demonstrates the coherence of the science content in the lesson, with facts linked to a key concept, 'properties' of substances; how this coherence was achieved through dialogic interaction patterns in the discourse; and how the teacher utilised the learners' home language, isiXhosa, to systematically establish understanding of the concept in their home language and then transfer that understanding to English, in a process that could be termed pedagogical translanguaging.

Learners had conducted an experiment when they observed the colour and magnetism of two substances, iron filings and sulphur powder: Teacher B elicited that iron filings were silver-grey in colour and magnetic; sulphur powder was yellow in colour and non-magnetic. He concluded that these were the properties of the two substances. He then asked the class for a definition of the term 'properties.' The generalised concept of 'properties' was central to the section of work on the separation of mixtures as the key principle was that the method for separating a mixture was dependent on the difference in the properties of the substances in a mixture.

\begin{tabular}{|l|l|l|}
\hline & Teacher B & Learner/s \\
\hline 1. & $\begin{array}{l}\text { Heke [good]. Now we say these are the } \\
\text { properties, now, ndifuna [I want a] definition } \\
\text { okanye [or] what is the meaning of this word, } \\
\text { what is the meaning of this word, properties? } \\
\text { Properties, properties, so we used these two } \\
\text { things, ne [okay]? I-colour phaya [there] and } \\
\text { we used } i \text {-magnetism. And we say these are } \\
\text { the properties of what? Of iron. Iyavakala [is } \\
\text { it clear]? }\end{array}$ & \\
\hline 2. & $\begin{array}{l}\text { And we used i-colour phaya kwisulphur } \\
\text { [in sulphur], yellow colour; and it is not } \\
\text { magnetic. I-sulphur and we say these are } \\
\text { the properties of what? Of sulphur. So, what } \\
\text { can we say is the meaning of that word ... } \\
\text { properties? Mhmm? Usebenzise ingqondo, } \\
\text { [use your brains]. Properties? Things that } \\
\text { we use to what? Yitsho (nominates learner, } \\
\text { Nomsa), uthethele phezulu [tell us Nomsa and } \\
\text { speak up] }\end{array}$ & Learners: Yes \\
\hline 3. & \\
\hline
\end{tabular}




\begin{tabular}{|c|c|c|}
\hline & Teacher B & Learner/s \\
\hline 4. & & $\begin{array}{l}\text { Nomsa: Uxolo tishara, } \\
\text { ndicingintobana } \\
\text { ithetha ngempawu } \\
\text { zesulphur neze iron. } \\
\text { [sorry teacher I } \\
\text { think it relates to } \\
\text { the characteristics of } \\
\text { sulphur and iron] }\end{array}$ \\
\hline 5. & $\begin{array}{l}\text { Izphawu zentoni [characterictics of what]? } \\
\text { Zesulphur ne iron, ne [Of sulphur and iron, } \\
\text { okay]? }\end{array}$ & \\
\hline 6. & & Nomsa: Yes \\
\hline 7. & $\begin{array}{l}\text { Izangesilungu ke ngoku yiyo leyo. [Say it in } \\
\text { English, that is it.] Mhmm? }\end{array}$ & \\
\hline 8. & & $\begin{array}{l}\text { Nomsa: (does not } \\
\text { answer) }\end{array}$ \\
\hline 9. & $\begin{array}{l}\text { Impawu zizinto esizisebenzisa ukwenza } \\
\text { ntoni? [What do we use characteristics for?] } \\
\text { Ukuthini [to do what]? Sizibenzisa xa kutheni } \\
\text { [we use them when]? Mhmm? }\end{array}$ & \\
\hline 10. & & $\begin{array}{l}\text { Learner W: } \\
\text { Ukwahlula [to } \\
\text { distinguish] } \\
\end{array}$ \\
\hline 11. & $\begin{array}{l}\text { Ukwahlula, sizisebenzisa ukwahlula, [to } \\
\text { distinguish, we use them to distinguish]. } \\
\text { Ngesilungu sizaw'thi sizisebenzisa ukthini? } \\
\text { Kaloku sizaw'bhala ngesingesi. [in English } \\
\text { what would we say we use it for? Remember } \\
\text { you will be tested in English] }\end{array}$ & \\
\hline 12. & & Learner X: Difference \\
\hline 13. & $K u$ ? [What] & \\
\hline 14. & & \begin{tabular}{|l|}
$\begin{array}{l}\text { Learner X: It's a } \\
\text { difference }\end{array}$ \\
\end{tabular} \\
\hline 15. & It's a difference? & \\
\hline 16. & & Learner X: Yes \\
\hline 17. & $\begin{array}{l}\text { (points to another learner) Khaw'tsho ke } \\
\text { ubuzaw'thini wena [tell us what were you } \\
\text { going to say]? }\end{array}$ & \\
\hline
\end{tabular}




\begin{tabular}{|c|c|c|}
\hline & Teacher B & Learner/s \\
\hline 18. & & Learner Y: To divide \\
\hline 19. & $\begin{array}{l}\text { Omnye ubuzaw'thini? [Another one, what are } \\
\text { you going to say?] Mmh? }\end{array}$ & \\
\hline 20. & & Learner Z: Identify \\
\hline 21. & $\begin{array}{l}\text { Ubona le [you see there] ... to identify, to } \\
\text { identify, iyavakala? [is it clear?] }\end{array}$ & \\
\hline 22. & & Learners: Yees \\
\hline 23. & $\begin{array}{l}\text { Heke [good]! Uzaw'tsho ke nge silungu } \\
\text { [that is what you'll say in English]. You } \\
\text { can say we use } i \text {-properties to differentiate, } \\
\text { ukwahlulahlula, ne [differentiate, okay]? }\end{array}$ & \\
\hline 24. & & Learners: Yees \\
\hline 25. & $\begin{array}{l}\text { T: Heke [good] to differentiate, phakathi } \\
\text { kwezinto ezimbini [between these two things] } \\
\text { between the two things. Now, the properties } \\
\text { you can say, now these are the things, which } \\
\text { we use to identify something, iyavakala? [is it } \\
\text { clear?] }\end{array}$ & \\
\hline
\end{tabular}

Teacher B then proceeded to get the learners to look up the meaning of 'properties' in the glossary at the back of their textbook. A learner read out the definition: 'Properties: feature of something that can be used to identify.' Teacher B then went on to give an analogy for 'properties', likening them to familial features that could be used to identify family members:

\begin{tabular}{|l|l|l|}
\hline & Teacher B & Learner/s \\
\hline 26. & $\begin{array}{l}\text { like ehh ... like ehh ... children of the same } \\
\text { family, ne? Like phaya ekhaya [at home] we have } \\
\text { a ... we have a pointed nose, mhlawumbi [for } \\
\text { example]. Uba uyabona ukuba impumlo itsolo } \\
\text { uzawyazi ukuba longowakulo Thando [if you } \\
\text { notice that the nose is pointed then you will know } \\
\text { that this one is related to Thando] Now, thina } \\
\text { [we] we have ehh ... we have ehh ... at home we } \\
\text { have a chin. Uya bona uba isilevu sam ubasinjani } \\
\text { [do you see how my chin is shaped]? }\end{array}$ & \\
\hline 27. & \multicolumn{2}{|l}{} \\
\hline
\end{tabular}




\begin{tabular}{|l|l|l|}
\hline 28. & Teacher B & $\begin{array}{l}\text { Sitsolo [it is pointed] Now all my brothers are like } \\
\text { this. So, you can say that is a feature ... feature } \\
\text { that we use. Iyavakala [is it clear]? }\end{array}$ \\
\hline 29. & & Learners: Yes \\
\hline 30. & $\begin{array}{l}\text { Feature that we use to identify (indistinct) lento } \\
\text { [something]. }\end{array}$ & \\
\hline
\end{tabular}

Coherence in this excerpt is demonstrated in turns 1-25 as Teacher B scaffolded learners through the process of reporting on systematic observations of a practical activity (the colours and magnetism of sulphur and iron) to a generalisation about the properties of substances - thus constructing a vertical knowledge structure.

The coherence of the content in this excerpt was sustained though the teacher-led dialogic discourse, which was characterised by the contingent responsiveness of the teacher: the responses of learners provided the starting point for the next questioning triad as Teacher B linked ideas into a logical train of thought and engaged learners in co-constructing science knowledge.

Teacher B demonstrated what can be described as pedagogical translanguaging as he systematically elicited key ideas in the learners' home language, isiXhosa: 'izphawu' (characteristics); 'ukwahlula' (to distinguish) and then elicited the precise translation of these concepts into English: learners offered 'difference,' 'divide' and then the precise meaning of 'identify.' In this way Teacher B was teaching for transfer (Cummins 2008) of concepts across languages and was 'using languages in an integrated and coherent way to organise and mediate mental processes in learning' (Baker 2011: 288) as is characteristic of translanguaging.

In addition Teacher B engaged learners in bridging discourses (Gibbons 2006), by making a link between the scientific concept of 'properties' and an analogy of physical likenesses that distinguish families. He also made learners look up the definition of the term 'properties' in the textbook glossary and a dictionary, so supporting learning across the mode continuum.

\section{Conclusions}

The fine-grained analysis of the classroom language practices for teaching science in the multilingual context of South Africa showed how, in the practice of one teacher, the nuanced interplay of discourse interaction patterns and translanguaging practices contributed to the development of coherent science content knowledge. The data shown here can thus exemplify how, in often very deprived settings, a skilful combination of languaging and content helps 
to bridge the gaps between everyday ideas and language and scientific ideas and language; between exploratory talk, presentational talk and writing; and between the learners' home language and English; and so construct opportunities to learn science.

The findings indicate the potential for teacher development - both in the practices that appear to support opportunity to learn science and in the points of breakdown that indicate points of leverage for change. Educational failure for the majority of learners is a central question in South Africa today - a matter of human rights. The ideals of access, equity and social justice that have been central to education policymaking are a work in progress.

Research in applied linguistics that is directed towards problem-solving in the linguistically diverse and complex context of South Africa has wider application in other postcolonial and southern contexts where the tensions between linguistic diversity and linguistically differentiated access to learning continue to limit opportunities to learn.

\section{Endnotes}

1 Under apartheid, 'townships' were set up as dormitory suburbs for African people on the peripheries of towns and cities.

2 Recent findings published by Statistics South Africa (2017) showed that 55\% of South Africans were living in poverty - below R992 (£59) per person per month; unemployment rates were $27 \%$.

\section{References}

Alexander, R.A. 2000 Culture and pedagogy: International comparisons in primary education. Oxford: Blackwell Publishing.

Baker C. 2011 Foundations of bilingual education and bilingualism. 5th ed. Bristol: Multilingual Matters.

Bambgose, A. 1991 Language and the nation: The language question in SubSaharan Africa. Edinburgh: Edinburgh University Press.

Barnes, D. 1976, 1992 From communication to curriculum. Harmondsworth: Penguin Books

Bernstein, B. 1999 Vertical and horizontal discourse: An essay. British Journal of Sociology of Education, 20(2): 157-173.

Blackledge, A. and Creese, A. 2010 Multilingualism: A critical perspective. London: Continuum.

Canagarajah, S. 2011 Translanguaging in the classroom: emerging issues for research and pedagogy. Applied Linguistics Review, 2: 1-28. DOI: https:// doi.org/10.1515/9783110239331.1 
Christie, P. and McKinney, C. 2017 Decoloniality and 'model C' schools: Ethos, language and the protests of 2016. Education as Change, 21(3): 1-21.

Clegg, J. and Afitska, O. 2011 Teaching and learning in two languages in African classrooms. Comparative Education, 47(1): 61-77.

Creese, A. and Martin P. 2008 Introduction to volume 9: Ecology of language. In Creese, A., Martin, P. and Hornberger, N.H. (eds), Encyclopedia of language and education. 2nd ed. Vol, 9: Ecology of language. New York: Springer. pp. xiii-Xviii.

Cummins, J. 2008 Teaching for transfer: Challenging the two solitudes assumption in bilingual education. In Hornberger, N.D. (ed.), Encyclopedia of Language and Education. New York: Springer. pp. 1528-1538.

Department of Education, RSA 1997 Language in education policy. Retrieved from http://www.education.gov.za

Donovan, M.S. and Bransford, J.D. 2005 Introduction. In Donovan, M.S. and Bransford, J.D. (eds), How students learn: Science in the classroom. pp. 1-26. Retrieved from http://www.nap.edu/catalog/11102/how-students-learnscience-in-the-classroom.

Ferguson, G. 2003 Classroom code-switching in post-colonial contexts: function, attitudes and policies. AILA Review 16: 38-51.

Fleisch, B. 2008 Primary education in crisis: Why South African schoolchildren underachieve in reading and mathematics. Cape Town: Juta.

Garcia, O. 2009 Bilingual education in the 21st century: A global perspective. Chichester: Wiley-Blackwell.

Gibbons, P. 2006 Bridging discourses in the ESL classroom: Students, teachers and researchers. London: Continuum.

Heugh, K. 2002 The case against bilingual and multilingual education in South Africa: Laying bare the myths. Perspectives in Education, 20(1): 171-196.

Howie, S. Combrinck, C., Roux, K., Tshele, M., Mokoena, G. and Palane, N.M. 2017 Progress in International Reading Literacy Study 2016: South African children's reading literacy achievement. Pretoria: Centre for Evaluation and Assessment, Pretoria University.

Lemke, J.L. 1990 Talking science: Language, learning and values. Norwood, NJ: Ablex Publishing Corporation.

Lewis, G., Jones, B. and Baker, C. 2012 Translanguaging: Developing its conceptualisation and contextualisation. Educational Research and Evaluation: An International Journal on Theory and Practice, 18(7): 655-670.

Macdonald, C.A. 1990 Swimming up the waterfall: A study of school-based learning experiences. A final report of the Threshold Project. Pretoria: HSRC.

McDonnell, L.M. 1995 Opportunity to learn as a research concept and policy instrument. Educational Evaluation and Policy Analysis, 17(3): 305-322.

Mercer, N. 1995 The guided construction of knowledge: Talk amongst teachers and learners. Clevedon: Multilingual Matters.

Mercer, N. 2004 Sociocultural discourse analysis: Analysing classroom talk as a social mode of thinking. Journal of Applied Linguistics, 1(2): 137-168. 
Mortimer, E.F. and Scott, P.H. 2003 Meaning making in secondary science classrooms. Maidenhead: Open University Press.

Plüddemann, P. 2015 Unlocking the grid: Language-in-education policy realisation in post-apartheid South Africa. Language and Education, 29(3): $186-199$.

Probyn, M. 2001 Teachers' voices: Teachers' reflections on learning and teaching through the medium of English as an additional language in South Africa. International Journal of Bilingual Education and Bilingualism, 4(4): 249-266.

Probyn, M.J., Murray, S., Botha, L., Botya, P., Brooks M. and Westphal, V. 2002 Minding the gaps - an investigation into language policy and practice in four Eastern Cape districts. Perspectives in Education, 20(1): 29-46.

Probyn, M. 2009 Smuggling the vernacular into the classroom: Conflicts and tensions in classroom code-switching in South Africa. International Journal of Bilingual Education and Bilingualism, 12(2): 123-136.

Reddy, V., Zuze, T.L., Visser, M., Winnar, L., Juan, A., Prinsloo, C.H., Arends, F. and Rogers, S. 2015 Beyond benchmarks: What twenty years of TIMSS data tells us about South African education. Cape Town: HSRC Press.

Republic of South Africa 1996 The Constitution of the Republic of South Africa. Retrieved from http://www.gov.za/documents/constitution/1996/ a108-96.pdf

Scott, P., Mortimer, E. and Ametller, J. 2011 Pedagogical link-making: A fundamental aspect of teaching and learning scientific conceptual knowledge. Studies in Science Education, 47(1): 3-36.

Setati, M., Adler J., Reed, Y. and Bapoo, A. 2002 Code-switching and other language practices in mathematics, science and English language classrooms in South Africa. In Adler, J. and Reed, Y. (eds), Challenges of teacher development: An investigation of take-up in South Africa. Pretoria: Van Schaik Publishers. pp. 73-93.

Thomas, W. and Collier, V. 2002 A national study of school effectiveness for language minority students' long-term academic achievement. Retrieved from http://www.thomasandcollier.com/assets/2002_thomas-and-collier_2002final-report.pdf [Last accessed 4 February 2019].

UNESCO 1953 The use of vernacular languages in education. UNESCO: Paris. Wellington, J. and Osborne, J. 2001 Language and literacy in science education. Buckingham: Open University Press.

Wells, G. 1999 Dialogic inquiry: Towards a sociocultural practice and theory of education. Cambridge: Cambridge University Press. 